\title{
STRATEGIC PLAN FOR THE DEVELOPMENT OF THE WEST CENTER/BRAZIL
}

\author{
LIMA, Leandro Oliveira de; ${ }^{a *}$ AURÉLIO NETO, Onofre Pereira ${ }^{\mathrm{b}}$
}

\begin{abstract}
(a) Dsc. in Geography, Lecteur University Federal of Goias (UFG). http://lattes.cnpq.br/9322069869687533
\end{abstract}
(b) Phd Student, University Federal of Goias (UFG). http://lattes.cnpq.br/9751444279688321

\section{(*) CORRESPONDING AUTHOR}

Address: Av. Deusdeth Ferreina, CEP: 74000000, Goiás (GO), Brasil. Tel: (+55 62) 39362160

E-mail: leandrolima.ufg@gmail.com

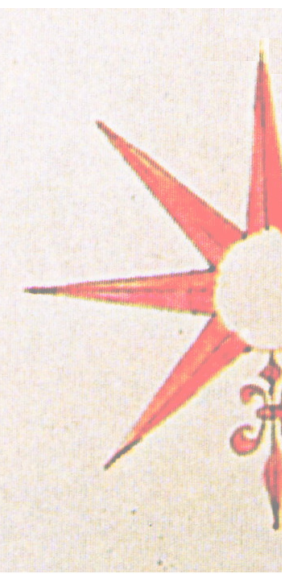

\begin{abstract}
This article offers an assessment of the Strategic Development Plan for Brazil's Centre-West (2007-2020), with special focus on the possible territorial impacts in the region caused by actions implemented by the Centre-West's Development Superintendence up to 2015. As far as methodology is concerned, this study presents a review of the literature which correlates notions of regionalization found in the document under analysis with those acknowledged by Geography and related fields. Furthermore, it brings forth selected secondary data and mappings of transport modes to foster a discussion on the region's economic integration and development policy.
\end{abstract}

Keywords: Regional Development; Integration; Centre-West region.

\section{RESUMO/ RESUMEN}

\section{PLANO ESTRATÉGICO DE DESENVOLVIMENTO DO CENTRO OESTE/BRASIL}

O texto apresenta uma avaliação do Plano Estratégico de Desenvolvimento do Centro Oeste (2007-2020) discutindo, a partir da proposta feita pelo documento, possíveis impactos territoriais no Centro Oeste brasileiro decorrentes de ações implementadas pela Superintendência de Desenvolvimento do Centro Oeste até 2015. Metodologicamente o texto contou com revisão de literatura correlacionando as ideias de regionalização presentes no documento àquelas reconhecidas pela Geografia e areas afins. Além disso, o texto apresenta dados secundários selecionados e mapeamento vinculados aos modais de transportes com o objetivo de discutir a integração economica e a política de desenvolvimento regional do Centro-Oeste.

Palavras-chave: Desenvolvimento Regional; Integração; Centro Oeste.

\section{PLAN ESTRATÉGICO DE DESARROLLO DEL CENTRO-OESTE/BRASIL}

Este artículo presenta una evaluación del Plan Estratégico de Desarrollo de la región Centro-Oeste de Brasil (2007-2020), tomando como base la propuesta hecha por el document se discutió los posibles impactos territo-riales en la región provocados por las acciones implementadas por la Superintendencia de Desarrollo de Centro-Oeste hasta 2015. Metodológicamente el texto presenta una revisión de la literatura que correlaciona las ideias de regionalización presentes en el document con las nociones reconocidas por la Geografía y áreas afines. Además, el texto presenta datos secundarios seleccionados y mapeo vinculados a los modales de transporte para discutir la integración económica y la política de desarrollo regional del Centro-Oeste

Palabras clave: Desarrollo Regional; Integración; Región Centro-Oeste. 


\section{INTRODUCTION}

Writing an article on regional planning and development in a post-Brexit scenario, on an international scale, and in view of the massive fiscal adjustment that calls into question the role of the Brazilian State, is not an easy task. On a macroeconomic level, the historical influence of the European Union (EU) on the consolidated theory of region and contemporary regionalization is all too evident. Nevertheless, in Brazil, one cannot overlook the successive efforts of experienced public policy experts regarding the current theoretical framework on regional issues. The EU case is by far the best-known and most consolidated experience of regional development yet recorded in the literature, according to Galvão (2004).

In Brazil and Latin America, the demand for regional development policies has been a major issue in governments' agenda since the founding of the Economic Commission for Latin America and the Caribbean (ECLAC). Even so, this article insists on adopting a critical view on the topic by addressing the role of regional planning which has been applied to Brazil's Centre-West region, via the assessment of territorial impacts and of logistics in the integration of the country's savannah. More specifically, this article focuses on the Strategic Development Plan for Brazil's Centre-West [Plano Estratégico de Desenvolvimento do Centro-Oeste - PED-CO] as part of the New National Policy of Regional Development [Nova Política Nacional de Desenvolvimento Regional - PNDR].

This study has endorsed the concept of region as a mediating scale between socio-economic and cultural dynamics and flows that affect a wide array of locations, as proposed by Lencioni (2003). The reason for this conceptual choice is that PED-CO, devised by the Ministry of National Integration as an instrument with the power to intervene on and overcome regional disparities, offers an optimized methodological structure and diagnostics to assess such disparities.

This article has three sections. The first compares theoretical elements from the New PNDR and PED-CO with previous experiences of regional development, hence showing the maintenance of theoretical and innovative weaknesses in the planning instrument assessed. The second section offers a broad characterization of the goals of the Centre-West's regional development policy stated in PED-CO, based on the notion of territorial integration, in an attempt to address the limits of such a spatial effect. The third and final section presents secondary data that made it possible to assess PED-CO's efficiency with regard to the territorial impacts on certain historically consolidated regional features.

\section{THEORETICAL ANALYSIS OF REGIONAL PLANNING AND OF PED-CO}

Devised to oversee federal government investments from 2007 to 2020, PED-CO springs forth from the agenda of the savannah's economic and territorial development as a milestone in regional planning policies. However, the document contains theoretical features that precede its drafting and warrant a more detailed analysis.

In Brazil, regional development policies stem from a particular notion of development based on a fundamental principle, which is very common in other parts of the world: that of economic growth. Grounded on the idea that it is possible to interfere in capitalism's unequal and combined spatial reproduction, many cities, especially those showing features of innovation poles, have functioned as spearheads of the dissemination of wealth produced by urban industrialization throughout the local territory. Following this notion, Perroux's (1975) concept of growth poles appears in a wide range of former development plans in Brazil, such as the First and Second National Development Plans (BRASIL, 1971b, 1974) and even those devised at regional level, e.g. plans by the North-East Development Superintendence [Superintendência de Desenvolvimento do Nordeste - Sudene] and 
the Centre-West Development Superintendence [Superintendência de Desenvolvimento do Centro-Oeste-Sudeco], which to some extent referred to the scale of the established urban network. Such an assumption, despite being only implicit in PED-CO's theoretical framework, inevitably comes through in its mappings.

According to information provided by PED-CO, investments focus on a historically consolidated urban network, particularly on certain production specializations (weaving, mineral production, chemical plants, steel industry, etc.) in specific cities in the Centre-West. In Goiás state, for instance, priority has been given to two mineral exploration sites in its northern portion, two metropolitan environments (Goiânia and Brasília), and two other 'winning regions' - to recall Benko and Lipietz's (1994) concept -, i.e. the south-east and the south-west. In Mato Grosso state, attention is given to the role played by agribusiness cities such as Sinop, Cáceres, and Rondonópolis, as well as Dourados in Mato Grosso do Sul state and the capital cities of both states (Cuiabá and Campo Grande, respectively), in the regional arena, particularly to the facilities of multinational company Bunge as a vector for regional development. On this topic, Elias (2012) stresses that the effects of agricultural financing policies have successively resulted in new territorial arrangements due to globalized agribusiness; such areas, selected to welcome the sector's major productive investments, have been named agricultural productive regions [Regiões Produtivas Agrícolas - RPAs] (ELIAS, 2012).

A central theoretical issue brought forth by PED-CO and verified in the history of regional planning, according to Dulong (1977) and Araújo (2000), refers to the fact that, in Brazil, regional development policies clearly endorse the notion of development adopted in the United States thanks, to a certain extent, to the experience of the Tennessee Valley Authority. Such policies are grounded on the triad regionalism as a political practice, gross increase in the production of grains and minerals of a given locality, and reduced effectiveness of the fight against regional inequality.

It is precisely within this context that the New PNDR emerges. Its executive summary ensures that the success of a regulatory framework seeking to tackle economic inequalities 'involves rejecting and overcoming [...] the unacceptable social and regional inequalities which are blindingly obvious for everyone and which make the daily lives of many people unbearable' (BRASIL, [2011], p. 7, our translation). However, it becomes evident that the PNDR's scope maintains, from the diagnostic based on the allocation and production of the gross domestic product (GDP) per capita, that the way to overcome such inequalities lies in consistently exploring endogenous development potentials in all Brazilian regions.

Certain terms found in both the New PNDR and PED-CO warrant attention, given that, far from lacking intentionality, they convey a political and ideological content that relates to contemporary forms of planning. Sachs (2000) and Esteva (2000) criticize the emergence of the term 'development' as being associated with industrial economic growth. In a similar vein, Escobar (2000) views planning as a modern rational instrument of annihilation of conventional structures. Hence, for this researcher, terms like 'competitive advantages', 'stagnation', 'endogenous regional development', 'local identities', 'fiscal war', and 'average income' convey a notion of strategic planning adopted by the New PNDR and PED-CO and thus demand a more profound theoretical analysis.

PED-CO states, for instance, that the development strategy 'cannot dispense with production growth or enhanced productivity, hence boosting competitiveness, but this cannot be achieved at the expense of environmental degradation, which deteriorates quality of life and reduces the very expansion possibilities of the regional economy' (BRASIL, [2007], p. 11, our translation). Such a statement confronts the very logic of the proposal that advocates the regionalization of public hearings on planning, given that it is exactly the expansion areas of commodities that are considered as venues for such events. As is widely known, agricultural production in the Centre-West is based on the expansion of agricultural credit and of the area for agriculture and cattle raising, as well as on the widespread use of chemicals for fertilization and species' extermination via intoxication. 1 In other words, even though the text's theoretical orientation recommends the conciliation 
of demands, financing policies move in the opposite direction to what is set out by instruments of territorial planning.

That is why strategic planning - strongly criticized by Souza (2006) - as recommended by PED-CO, based on a political process that unites and negotiates various social interests and, moreover, makes collective choices which reflect conflicts and convergences of social actors, tends to find in the regional arena (ARRAIS, 2009) a barren terrain of divergences for its effective application. On the other hand, strategic planning turns PED-CO into a harmless planning instrument, as the nine years of its lifetime have shown. As regards such obstacles to PED-CO, Escobar (2000) views rational planning as highly ideological, and it is through rationality that planning may develop. It cannot be denied, however, that PED-CO is guided by a principle of opposition of the normal trends of capitalist accumulation, as claimed by Galvão (2004).

The founding concept of the New PNDR is, therefore, in line with PED-CO's notion of sustainable regional development, 'conceived as the process of change that brings together an increase in economic competitiveness, improvement in the population's quality of life, and environmental conservation' (BRASIL, [2007], p. 10-11, our translation). Such a notion confers on the Centre-West a leading role in the distribution of commodities to foreign markets, as is pointed out by Araújo (2000). That is why PED-CO replaces the expression 'national barn', popular during Brazil's military regime, for 'solution region', given the Centre-West's economic performance and the little reliance of its production on federal investments and subsidies. Such a fact is confirmed by PED-CO's slogan: 'For the second wave of regional dynamism and economic expansion, the proper slogan appears to be: The Centre-West's competitive advantages open up great chances of success in business transactions with and through environmental conservation' (BRASIL, [2007], p. 40, our translation, emphasis added).

The methodologies brought forth by the New PNDR and by PED-CO highlight the variables involved in the relation between the regional GDP per capita and the national average from 1949 to 2000. As regards the nature of unequal per capita distribution, a factor which directly affects regional inequality, the role of cities in the regional context is implicit when one analyzes the territory's financing policies at state level - as is the case of Goiás state, for instance - as well as housing funding programmes, which generally focus on the state's metropolitan regions, Goiânia and Brasília.

Another factor that corroborates this argument is that, in the data series provided by PED-CO, the performance of Goiás in comparison with other states remains highly favourable due to the central role played by the federal capital and by the city of Goiânia. In other words, even though the theoretical matrix recommended by the New PNDR and by PED-CO is crucial to understanding poverty distribution on a regional scale, the very nature of income inequality among the population does not correspond to the scenarios devised to overcome regional disparities, so much so that the decreasing urbanization rate presented by PED-CO's time series highlights the role played by cities. In short, what might be the great contribution of recent planning resources, i.e. viewing regional endogeny as the solution for income inequality throughout the territory reinforces the role of regionalisms which currently make up the Centre-West.

\section{INTEGRATION AND REGIONAL DEVELOPMENT POLICY IN THE CENTRE-WEST}

According to Andrade (1976, p. 41, our translation), regional development policies must 'guide economic growth to a common ground between the possible uses of resources and their maximum preservation in each region'. Hence regional planning must address socioeconomic and environmental issues in order to reorganize activities and promote a more effective use of space and its natural resources. 
However, from the 1960s to the 1990s, natural resources were pushed into the background by regional development projects for the Centre-West (CHAVES, 2008), and the savannah was simply regarded as an area of agricultural and cattle raising expansion, whose vegetation should be removed for planting crops and breeding cattle. Production would focus on supplying both foreign and domestic markets.

PED-CO, also named Regional Development Plan for the Centre-West [Plano Regional de Desenvolvimento do Centro-Oeste-PRDCO], modifies this perspective by adopting the concept of sustainable regional development to strike a balance between the rise in economic competitiveness and improvements in quality of life for the population with the region's environmental conservation.

Devised by the Ministry of National Integration, PRDCO has as its general aim 'to promote a new orientation of the Region's development style that leads to sustainable development, hence expressing society's vision of the future' (BRASIL, [2007], p. 150, our translation, emphasis in the original). To achieve this, the Plan recommends the combined implementation of economic, social, and environmental development projects, involving governments at federal and state levels and several segments of society.

In accordance with PRDCO, action priorities for regional development consist in solving bottlenecks and making proper use of the potentials of the Centre-West. Six development vectors are presented: 1) Democratization and improvements in public management; 2) Environmental management and recovery; 3) Improvement in education and consolidation of Research and Development (R\&D); 4) Expansion of social and urban infrastructure; 5) Expansion of economic and logistic infrastructure; 6) Diversification and densification of productive chains (BRASIL, [2007]).

Therefore, the 2007 edition of PRDCO distances itself from previous plans and programmes in that it aims to increase regional competitiveness and improve the population's quality of life by balancing these aims with the conservation of ecosystems, which leads to sustainable development. PED-CO is part of Sudeco's reconstruction process, and it is up to this planning organization to carry out the tasks of managing, updating, and implementing the Plan, in accordance with its regulation by presidential decree number 7,471, passed on May 4th 2011 (BRASIL, 2016).

Sudeco was initially set up by Law number 5,365, passed on December 1 1967, to address the drafting of programmes, research studies, and surveys on the Centre-West's economic potential (BRASIL, 1967). Its major aims are expansion of the agricultural border and demographic and productive occupation of the region, to be achieved through immigration/populating policies, establishment of growth poles, increase in infrastructure, and use of lands in primary activities.

Expanding the agricultural border in accordance with modern agriculture and cattle raising has been part of the demands of the industrial sector and of multinational groups set up in Brazil, particularly in the South-East Region (Cavalcanti \& Barreira, 2011). These groups demanded large amounts of raw materials for processing and transformation. In practice, incorporating the Centre-West into large-scale production required the State's technical and financial intervention.

Such demands were met through programmes targeted at expanding transport networks as well as through agricultural credit policy, expansion and industrialization of agricultural and cattle raising production, use of chemicals for soil fertilization, adaptation of exogenous species, and mechanization of production. The National Development Plans and their respective programmes of economic development, carried out at the expense of natural ecosystems during the 1970s, are examples of the process at hand.

The first National Development Plan [Plano Nacional de Desenvolvimento -PND], established by Law number 5,727, passed on November 4th 1971 (BRASIL, 1971b), came into effect from 1972 to 1974 and applied most of its resources to the implementation of basic infrastructure, aiming at increasing the country's production in strategic sectors and the exports of primary products. The Centre-West's Development Programme [Programa de Desenvolvimento do Centro-Oeste - Pro- 
doeste] helped expand Brazil's road network by fostering the construction of roads and highways that would physically integrate several regions (BRASIL, 1971a).

The task of integrating the Centre-West was assigned to highways e.g. the Brasília-Acre integrating highway (BR-364), which passes through the states of São Paulo, Minas Gerais, Goiás, Mato Grosso, Rondônia, and Acre. Having succeeded the Goiás Railway, highways intensified relations between the Centre-West and the South-East, the country's main economic and industrial hub. As claimed by Rodrigues (2011), despite the high costs of road transport - due mainly to energy consumption - in distances greater than 500 kilometers, this mode of transport received the biggest boost in Brazil with the expansion of roads and highways.

In the second PND (1975-1979), established by Law number 6,151, passed on December 4th 1974 (BRASIL, 1974), the Brazilian government aimed at increasing the production of food, basic consumables, capital goods, and energy based on a strategy of national industrialization and integration with the global economy. This Plan brought to the fore a policy aimed at the expansion of planting areas, the production of agricultural machinery and chemical consumables, as well as at the energy, infrastructure, and modernization of rural production.

Following on from the second PND, the Development Programme for the Savannah [Programa de Desenvolvimento do Cerrado - Polocentro] was established by Decree number 75,320, passed on January 29th 1975 (BRASIL, 1975). The programme's objective consisted in 'fostering the development and modernization of agricultural and cattle raising activities in the Centre-West Region and in the western portion of Minas Gerais state, through rational occupation of selected areas which offer typical savannah features' (BRASIL, 1975, our translation). According to Goodland and Ferri (1979), the Polocentro programme steered agricultural and cattle raising exploitation towards the savannah and away from the Amazon, a biome then considered less relevant.

Programmes encouraging the incorporation of new areas in the Centre-West into the production process increased the total area of agricultural and cattle raising establishments assigned for temporary farming, from 2.25 million hectares in 1970 to 6.16 million hectares in 1980, reaching $6,329,816$ hectares in 1995 . In Goiás state, the total area for temporary farming went from 1.55 million hectares to 3.1 million hectares between 1970 and 1980 (Table 1).

Table 1 - Area (in hectares) of agricultural and cattle raising establishments which used lands for temporary plantations and planted pastures in 1970, 1980, and 1995

\begin{tabular}{|c|c|c|c|c|c|c|}
\hline \multirow{2}{*}{ Federative Units } & \multicolumn{3}{|c|}{ Temporary Plantations (ha) } & \multicolumn{3}{c|}{ Planted Pastures (ha) } \\
\cline { 2 - 7 } & 1970 & 1980 & 1995 & 1970 & 1980 & 1995 \\
\hline Distrito Federal & 8,530 & 49,566 & 61,243 & 15,740 & 59,460 & 62,443 \\
\hline Goiás & $1,557,711$ & $3,104,289$ & $2,119,066$ & $4,362,064$ & $10,843,662$ & $14,267,411$ \\
\hline Mato Grosso & 693,116 & $1,423,448$ & $2,782,011$ & $4,695,690$ & $4,693,320$ & $15,262,488$ \\
\hline Mato Grosso do Sul & - & $1,589,475$ & $1,367,496$ & - & $9,068,931$ & $15,727,930$ \\
\hline Centre-West Region & $2,259,357$ & $6,166,778$ & $6,329,816$ & $9,073,494$ & $24,665,373$ & $45,320,272$ \\
\hline
\end{tabular}

Source: INSTITUTO BRASILEIRO DE GEOGRAFIA E ESTATÍSTICA, [2016a].

Over the same period, planted pastures in the Centre-West increased $171.8 \%$. In 1995, the agricultural and cattle raising census recorded more than 45.3 million hectares of planted pastures in the region. In Mato Grosso state, for instance, from 1980 to 1995, planted pastures went from 4.6 million hectares to $15,262,488$ hectares.

The construction of Brasília in the 1950s also dynamized the Centre-West through the road network built to integrate the Federal District, as well as through the demand for food and other products that began flowing from the other regional states towards the new capital. It was during this period that construction of the Belém-Brasília highway began, one of the country's major road connections and a symbol of national integration, which links the Federal District to the North and South regions. 
Transport systems in the Centre-West were implemented to enable local production to circulate and, to a lesser extent, served as an axis for populational growth. According to Santos and Silveira (2012), urban settlements and cities were gradually formed on the sides of highways and railways and grew following their trajectory. Rural exodus, in turn, triggered by the modernization of the countryside, led to populational concentration in cities, mainly in capitals and nearby urban settlements. These phenomena led to the increase of the region's urban population, from 995,000 in 1960 to 2.3 million in 1970 and 4.9 million in 1980 (Figure 1).

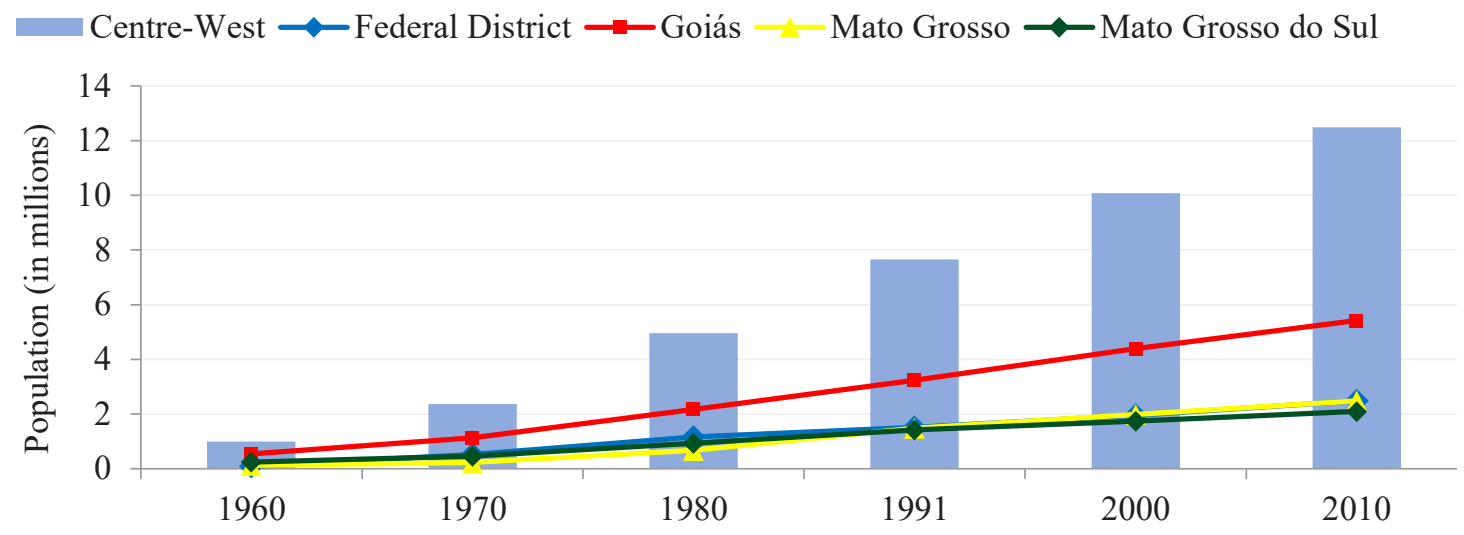

Figure 1 - Growth of the urban population in the Centre-West from 1960 to 2010 Source: INSTITUTO BRASILEIRO DE GEOGRAFIA E ESTATÍSTICA, [2016c].

In 2010, the Goiânia-Anápolis-Brasília axis, made up of Goiânia’s metropolitan region [Região Metropolitana de Goiânia - RMG] (2,173,141 inhabitants), Anápolis' microregion (540,220 inhabitants), and the integrated development region of the Federal District and its surroundings [Região Integrada de Desenvolvimento do Distrito Federal e Entorno - Ride] (3,717,728 inhabitants) concentrated the largest populational group in the Centre-West: $45.7 \%$ of a total of 14,058,094 inhabitants (INSTITUTO BRASILEIRO DE GEOGRAFIA E ESTATÍSTICA, [2016b]). Such a considerable demographic concentration stems from the polarization shown by these urban centres, which perform administrative and commercial roles as well as offer a wide range of services.

As claimed by Chaves (2008), the rapid process of incorporating new areas for agricultural and cattle raising expansion in the region during the last few decades has led to expansion of the area of capital reproduction; increase in the production of commodities; greater dependence on demands from other regions; demographic growth; growth of cities which absorbed the rural population; several environmental impacts (deforestation, pasture degradation, acceleration of erosional processes, disturbance of water balance involving incorrect uses of irrigation systems, eutrophication, and contamination of water springs via toxic agrochemicals, etc.).

In the current PRDCO, natural resources and biodiversity come through as two of the region's major features. The degradation of regional ecosystems poses one of the biggest threats to regional development, together with the vulnerability of an economy grounded on commodities; low productive diversification and densification of productive chains; logistical dismantling and bottlenecks in economic infrastructure; growth of informal economy; dismantling of urban networks; deficiencies in workforce qualification; high poverty rates; great concentration of wealth; insufficient offer of social services (BRASIL, [2007]).

To overcome these problems, PED-CO establishes as its global aims: reduction of the deforestation rate and recovery of deforested areas in regional ecosystems; increase in the number of homes with water supply and sewage systems; reduction of child mortality; reduction of poverty rates; reduction of concentration of wealth; increase in the average educational level; reduction of illiteracy rates; economic growth; diversification of exports; improvements in the regional road 
network, etc. (BRASIL, [2007]). The current status of these global aims will be discussed in the following section, which addresses the impacts posed by PED-CO.

\section{PED-CO'S ECONOMIC, SOCIAL, AND ENVIRONMENTAL AIMS AND IMPACTS}

Ranking among PED-CO's aims is the diversification of the Centre-West's export agenda from 2007 to 2020, which is to result in export increase, competitiveness in other sectors, and less vulnerability from internal and external alterations, e.g. climate hazards and sudden drops in the price of commodities. However, little has been achieved in this regard, with exports still focusing on few commodities, such as soybean, corn, and beef.

In 2007, the four major items of the region's export agenda amounted to $61.5 \%$ of sales (Table 2). In 2015, the four main export items were still soybean (34.5\%), corn grain (15.1\%), pulp and other solid residues from the extraction of soy oil (9.0\%), and frozen boneless beef (7.9\%). During this period, the concentration of these products in the region's export agenda increased, totalling $66.5 \%$ of sales in 2015; exports of primary products, therefore, prevailed. This reveals difficulties in achieving the diversification aim by 2020 .

Table 2 - Main items in the Centre-West's export agenda, in 2007 and 2015

\begin{tabular}{|c|c|c|c|c|}
\hline \multirow{2}{*}{ Export Product } & \multicolumn{2}{|c|}{$\mathbf{2 0 0 7}$} & \multicolumn{2}{|c|}{$\mathbf{2 0 1 5}$} \\
\cline { 2 - 5 } & Value (US\$ FOB) & $\%$ & Value (US\$ FOB) & $\%$ \\
\hline Soybean, including ground soy, except for sowing & $2,819,717,471$ & 29.1 & $8,281,857,822$ & 34.5 \\
\hline Corn grain, except for sowing & $967,903,733$ & 10.0 & $3,607,899,227$ & 15.1 \\
\hline Pulp and solid residues from the extraction of soy oil & $1,112,752,561$ & 11.5 & $2,160,942,294$ & 9.0 \\
\hline Frozen boneless beef & $1,061,770,199$ & 11.0 & $1,884,043,052$ & 7.9 \\
\hline Other products & $3,732,207,589$ & 38.5 & $8,037,099,826$ & 33.5 \\
\hline TOTAL & $9,694,351,553$ & 100.0 & $23,971,842,221$ & 100.0 \\
\hline
\end{tabular}

Source: BRASIL [2016a].

Exports from Centre-West states and the Federal District totalled 9.6 billion dollars in 2007 and 23.9 billion dollars in 2015 (BRASIL, [2016?a]). Such a rise in export figures may be accounted by new international trade agreements, increase in the number of exporters, increment in production, and improvements on transport infrastructure and on products, which has led to greater acceptance of Brazilian products in foreign markets. Figure 2 shows the main destinations of products from the Centre-West in 2015.

China has proved to be a strong trade partner for the region, accounting for $29.8 \%$ of exports, or 7,149,402,065 dollars. It has imported mostly soy grains and by-products. The Netherlands is another major import market for Centre-West's products, having accounted for $6.3 \%$ of exports. Also in 2015, Asia topped the list of economic blocs that most contributed to the region's exports (56.1\%), followed by the EU (17\%) (BRASIL, [2016?a]).

Highways BR-163, BR-060, and BR-364 are the main routes for the Centre-West's export products, leading to ports in Paranaguá (Paraná state) and Santos (São Paulo state). According to Correa and Ramos (2010), due to highways' bad conditions, inadequate infrastructure, and high average freight costs (ton/kilometre), about a quarter of soybean sale revenues is jeopardized by internal transport costs, ultimately inflicting losses on the Centre-West's agribusiness competitiveness due to the so-called 'Brazil Cost' [Custo Brasil]. 


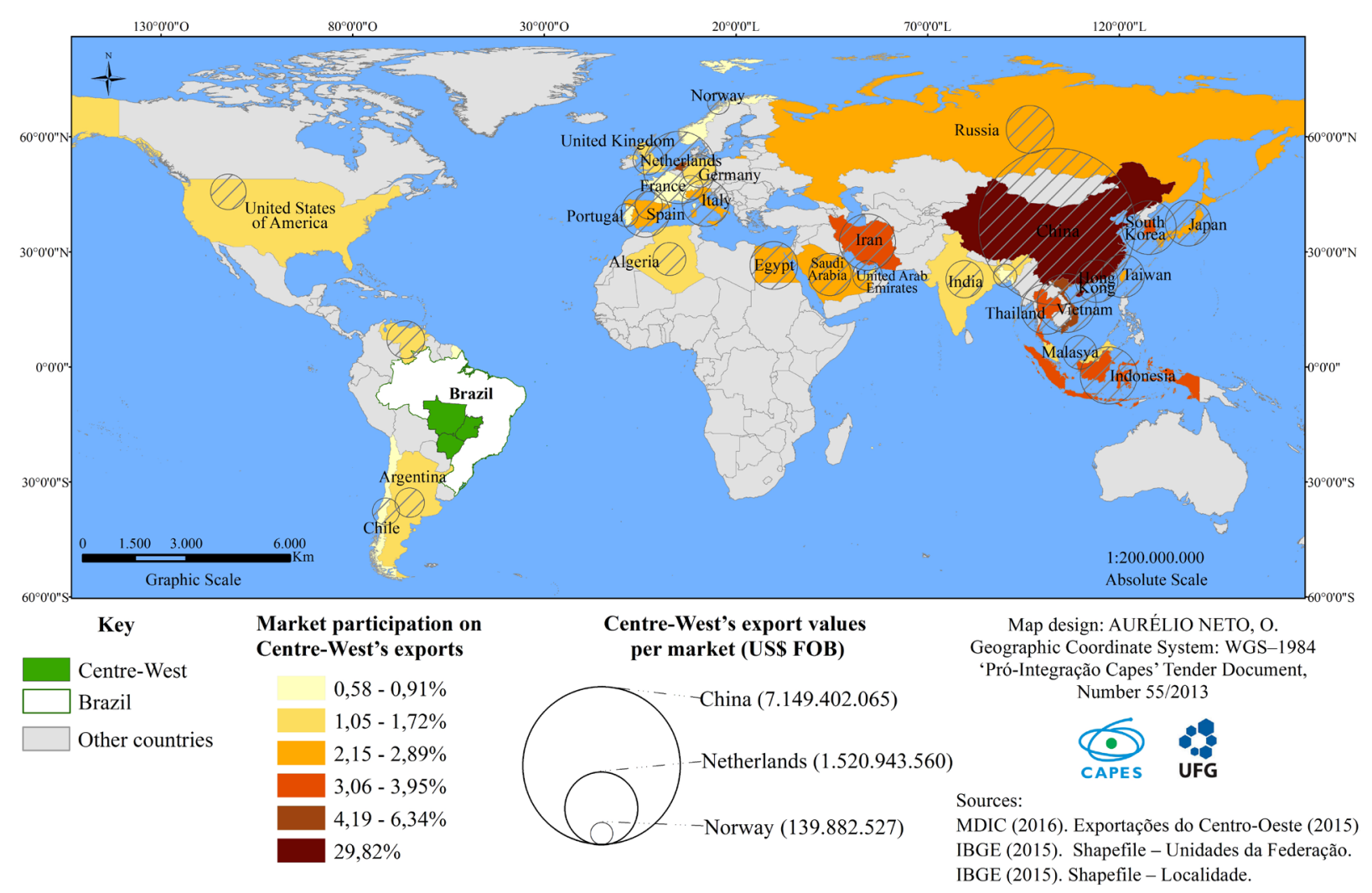

Figure 2 - Map of destination markets for Centre-West's export products, per exported volume, in 2015.

As far as traditional bulk goods are concerned, export corridors are supported by a multimodal transport network and by private ports specifically devised to distribute this type of commercial product. According to Barat (1969), transport corridors and trunk lines connect distant localities so that flows of goods can be transported between centres of production, transformation, and consumption; such corridors include transport modals, transshipment terminals, and operators, among other features. The most efficient transport corridors offer agility and reduced freight costs due to the fact that they include intermodality along their routes.

Despite improvements in the transport sector in recent years, intermodality remains restricted to a few locations in the Centre-West, such as the Dry Port in Anápolis. It is the region's main logistics hub, integrating road, rail, and air cargo transport modals to make up the Multimodal Logistics Platform of Goiás state (CASTRO, 2014). Other intermodal hubs include the road/river intermodal locations in Cáceres (Mato Grosso state), Porto Murtinho (Mato Grosso do Sul state), and São Simão (Goiás state), as well as the intermodal system (road, river, and rail modals) in Ladário (Mato Grosso do Sul state), all of which are shown in Figure 3. 


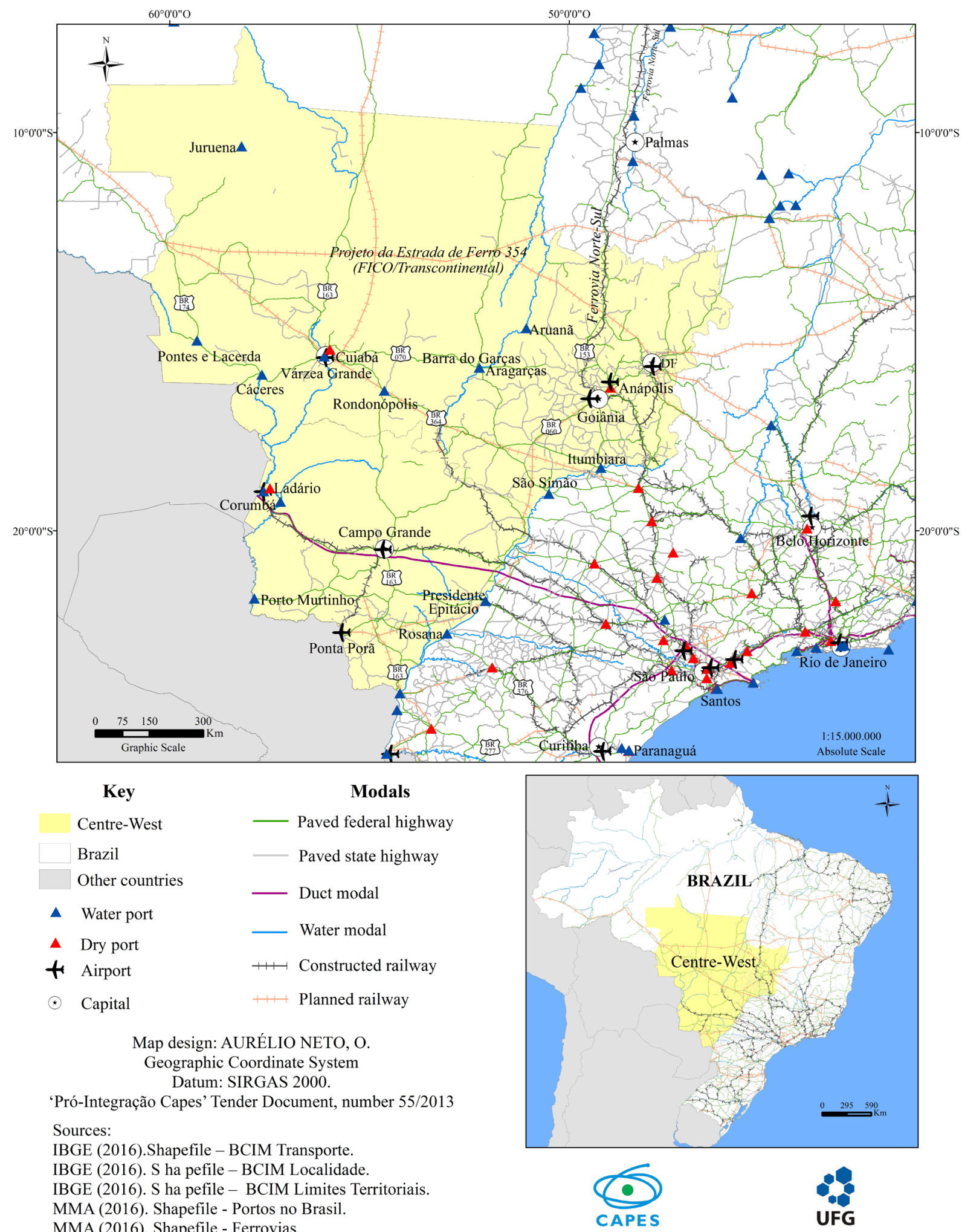

Figure 3 - Map of transport corridors in the Centre-West (2016). 
Investments in transport infrastructure help the economy by promoting the distribution of goods, market integration, and changes in commercial standards. In this regard, one of PED-CO's aims is to improve the regional road network. According to the Road Survey of the National Transport Confederation (CNT), of the 13,257 kilometres assessed in the Centre-West in 2007, only 21.5\% were considered good or excellent (Figure 4). In 2015, 15,257 kilometres of regional highways were assessed, and their general state was ranked as follows: $39.6 \%-$ good or excellent $(6,035$ kilometres), 37.2\% - average (5,676 kilometres), and 23.2\% - fair or poor (3,546 kilometres). The eighteen percent increase in the number of kilometres considered good or excellent stems from investments in the regional infrastructure, mostly provided by the government's Growth Acceleration Programme [Programa de Aceleração do Crescimento - PAC], launched in January 2007.

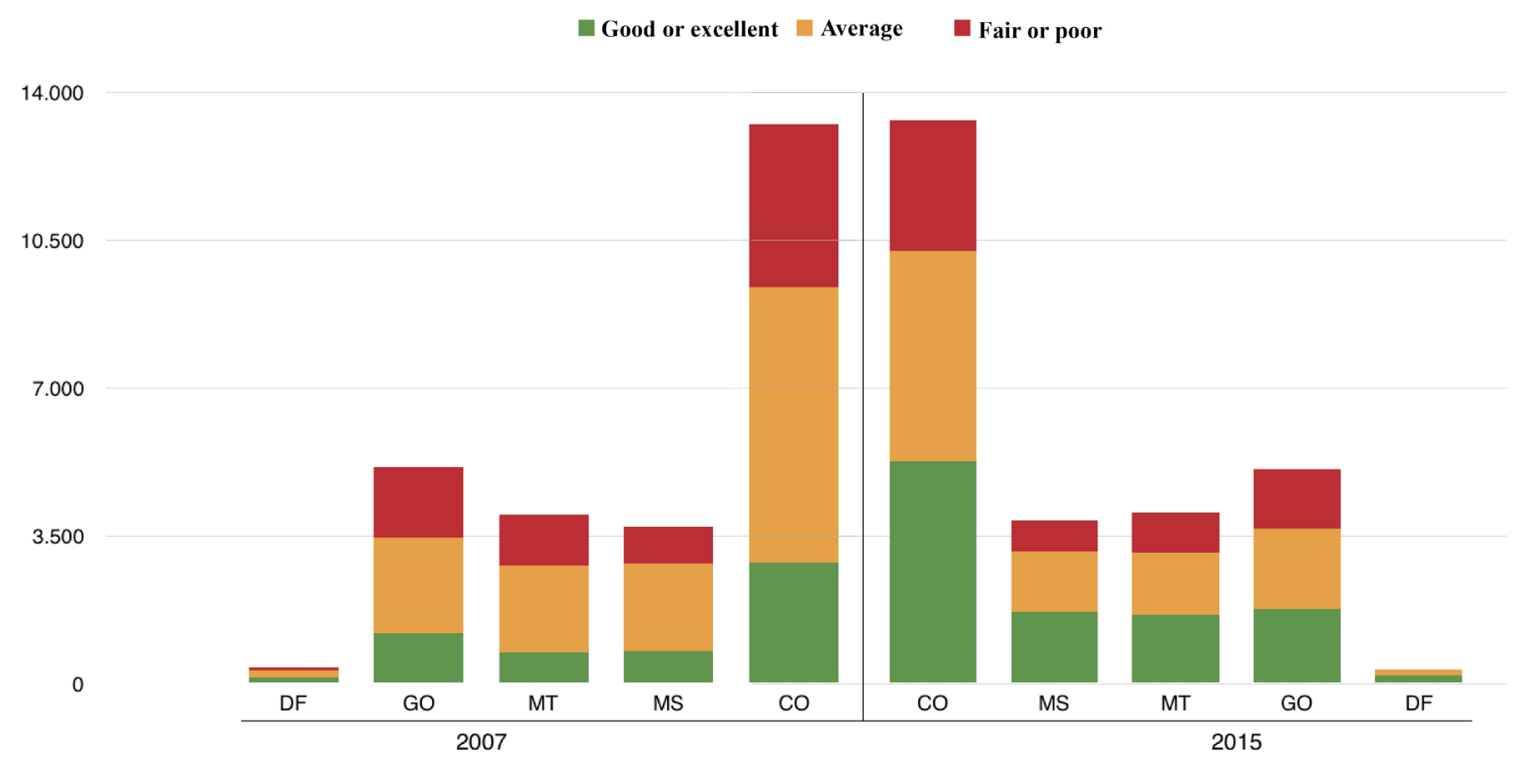

Figure 4 - Overall condition of highways (in kilometres) in the Centre-West, based on assessments made in 2007 and 2015.

Source: CONFEDERAÇÃO NACIONAL DO TRANSPORTE $(2007,2015)$.

PAC-based investments throughout Brazil totalled 1.9 trillion reais by 2015 (BRASIL, 2016). The programme has enabled PED-CO to achieve the goal of improving road networks by duplicating, paving, and integrating roads with other modals (railways and waterways). Nevertheless, a historical deficit remains in place and the granting of resources for the transport sector is insufficient, which may be aggravated by government cuts, both at federal and state level, over the next few years.

Investments on railway networks, on the other hand, including the construction of 1,550 kilometres of tracks on Railway 151 (North-South Railway), in the section between Anápolis and Açailândia (Maranhão state), will benefit the transportation of export cargoes along two new routes: passing through Goiás state up to Açailândia's marshalling yard and taking the Carajás Railway to the ports of Itaqui (Maranhão state) or of Belém/Vila do Conde (Pará state), if Railway 151 is in fact concluded. On the east-west axis, the project of Railway 354 (Fico/Transcontinental) includes the construction of a longitudinal railway line which will pass through Mato Grosso and Goiás states, hence connecting the Centre-West with Acre state, other South American countries, and the Atlantic coast.

Ports in the North and North-East regions offer advantages when compared to their counterparts in the South and the South-East, such as the limited number of transshipment operations, which affects the lead time for unloading and shipping products. Therefore, given that these ports are geographically closer to the major foreign markets i.e. Asian countries and EU members, the total costs of distribution logistics can be reduced.

PED-CO's environmental aim seeks to reduce deforestation in Centre-West biomes as well as use natural resources in a sustainable way. However, several studies have shown an increase in 
deforestation in the region, intensified by the advancement of agricultural and cattle raising areas in stretches of native vegetation. In Mato Grosso state, for instance, the Prodes project, devised by the National Institute of Spatial Research [Instituto Nacional de Pesquisas Espaciais - Inpe], has exposed ongoing deforestation of the Amazon forest's original cover over the last few decades, despite a variation in the annual deforestation rate between 2007 and 2015; a decreasing trend was observed from 2008 to 2014, when the deforestation rate yielded 1,049 and 1,075 square kilometres a year, respectively. In 2015, however, there was a $48.9 \%$ increase in relation to the previous year.

From 2007 to 2015, over 13,540 square kilometres were deforested in Mato Grosso's Legal Amazon area alone (INSTITUTO NACIONAL DE PESQUISAS ESPACIAIS, [2016]). The same period witnessed the expansion of the Centre-West's planted area for temporary farming, which went from 15,068,726 hectares in 2007 to 25,071,310 hectares in 2015 (INSTITUTO BRASILEIRO DE GEOGRAFIA E ESTATÍSTICA, [2016d]). Cultures with the largest planted areas were soybean, corn, sugar cane, and herbaceous cotton (Figure 5).

Soybean occupied over nine million hectares in 2007, which amounted to $60 \%$ of the region's total planted area for temporary farming. In 2015, it was cultivated in 14.6 million hectares, a $62.7 \%$ increase when compared to 2007 . This led to an increase in the amount of soy produced, from 26,201,565 tons to 43,943,604 tons over an eight-year period (INSTITUTO BRASILEIRO DE GEOGRAFIA E ESTATÍSTICA, [2016d]).

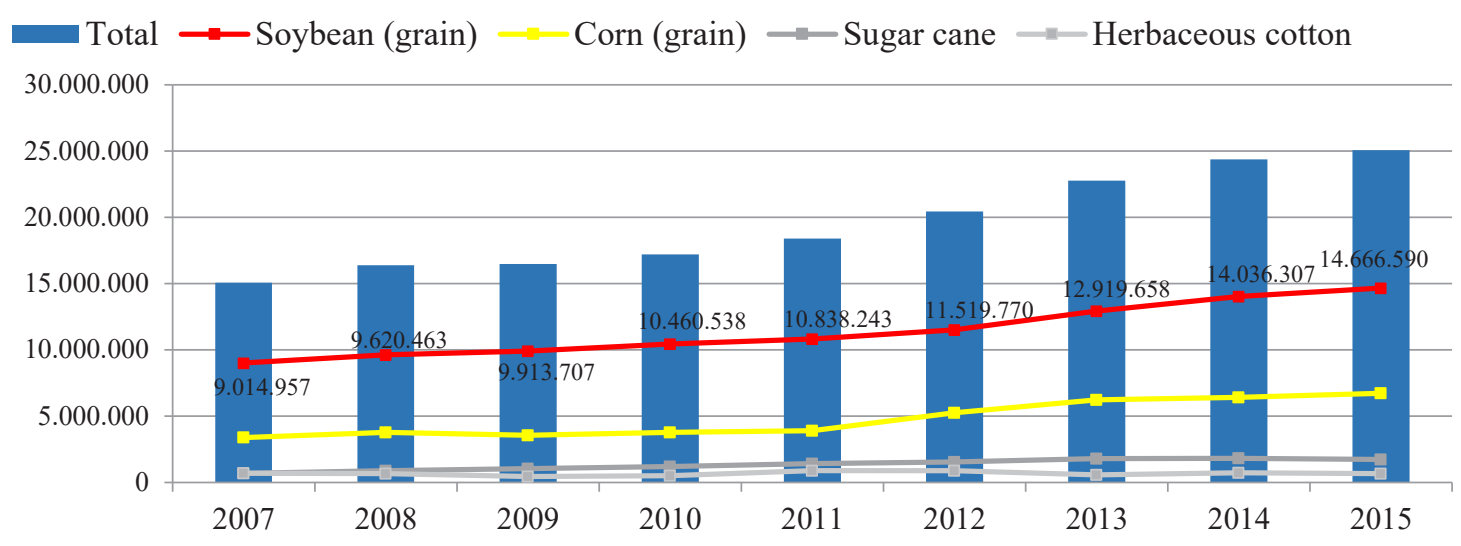

Figure 5 - Evolution of the Centre-West's planted area for temporary farming, showing the main cultures per hectare (2007-2015)

Source: INSTITUTO BRASILEIRO DE GEOGRAFIA E ESTATÍSTICA, [2016d].

As far as the development aim related to income concentration is concerned, income inequality still exists despite efforts to reduce it. In 2013, Brasília and Goiás state had the highest per capita income in the Centre-West, totalling 63,020 and 23,470 reais, respectively. However, the greatest bottleneck facing regional equality policies is directly linked to family income. Hence the impressive number of families from the Centre-West enrolled in governmental programmes like Bolsa Família [Family Allowance] in 2016 (Table 3).

Table 3 - Total number of families from the Centre-West which receive Bolsa Família and regional states GDP per capita

\begin{tabular}{|c|c|c|c|c|}
\hline Federative Units & $\begin{array}{c}\text { Total number of } \\
\text { families }\end{array}$ & $\begin{array}{c}\text { Number of families on } \\
\text { Bolsa Família }\end{array}$ & Variation \% & $\begin{array}{c}\text { GDP per capita - 2013 } \\
\text { (R\$) }\end{array}$ \\
\hline Goiás & 825,380 & 319,591 & 38.72 & 23,470 \\
\hline Distrito Federal & 224,579 & 84,614 & 37.67 & 63,020 \\
\hline Mato Grosso & 493,477 & 171,291 & 34.71 & 28,007 \\
\hline Mato Grosso do Sul & 435,849 & 136,063 & 31.21 & 26,714 \\
\hline TOTAL & $1,979,285$ & 711,559 & 35.9 & \\
\hline
\end{tabular}

Source: BRASIL [2016?b]; INSTITUTO BRASILEIRO DE GEOGRAFIA E ESTATÍSTICA, [2016e]. 
PED-CO takes into account the central role played by GDP per capita in the regional assessment of income concentration. In this regard, the Federal District has the highest GDP per capita in the Centre-West and even nationwide, given the centrality of public service in the Brazilian capital and the high salaries associated with it. However, when one compares the performance and functional role of income transfer programmes towards poor families, it becomes clear that the total percentage of families enrolled in Bolsa Família in 2016, from all three states and the Federal District, varies according to the correlation between the total number of beneficiaries and their concentration in metropolitan areas such as RMG and Ride. Such a dynamics is justified by two simple factors: first, the problem of the methodological distortion of wealth measured by the arithmetic mean; second, as is confirmed by PNDR's selected methodology, the poverty spread throughout Brazil, which holds a spatial and identity-related significance. These factors explain the increase in the number of families integrated into the Centre-West's income redistribution systems.

As regards the assessment of PED-CO's aim related to economic growth - based on PNDR's defined assumption of the redistributive nature of fundings, which entails that only the State has enough resources -, one must highlight the central role played by the Fund for the Participation of States and the Federal District [Fundo de Participação dos Estados e do Distrito Federal - FPE] and by the Fund for the Maintenance and Development of Basic Education and Enhancement of Education Professionals [Fundo de Manutenção e Desenvolvimento da Educação Básica e de Valorização dos Profissionais da Educação - Fundeb]. Together, they offer the highest sums of resources to Centre-West states, producing considerable regional impact.

In 2012, the Union transferred 3,270,763,225 reais to the Centre-West through FPE. Of this sum, $43.8 \%$ went to Goiás, $35.7 \%$ to Mato Grosso, and 20.5\% to Mato Grosso do Sul. Therefore, the nature of the federal government's capitalization via constitutional revenues does not change the endogenous regional framework since one of the elements that determine the amount of resources is demography, which reinforces previous regional inequalities to a certain extent. The same percentage variation can be observed in the balance sums transferred from 2012 to 2015.

As regards the dynamics of economic growth through the lens of states' GDP variation, however, it is clear that the greatest potential of regional development is directly linked to investments made by states themselves. In the Centre-West, Goiás showed the highest GDP from 2010 to 2013, followed by Mato Grosso and Mato Grosso do Sul. A substantial part of its wealth stems from financial mediation, insurance, and welfare; services (offered mostly to companies); real estate activities (rental and trade), and maintenance services (CONJUNTURA ECONÔMICA GOIANA, 2016). Also in 2013, Goiás was responsible for producing $48.8 \%$ of the region's total wealth as measured by GDP, not including the Federal District.

The Centre-West's wealth panorama changes significantly with the inclusion of the Federal District: $36.1 \%$ is produced by the Brazilian capital, $31.2 \%$ by Goiás, $18.4 \%$ by Mato Grosso, and $14.3 \%$ by Mato Grosso do Sul. However, given the specificities of income concentrated in the Federal District, i.e. as a result of the services it offers and of its limited territory within the Centre-West's entire area, the role played by Goiás in the region's positive progression of wealth prevails on a macro-regional assessment. As far as the aim of economic growth recommended by PED-CO is concerned, the role played by Brazil's federative units is crucial for regional dynamization, even though investments at state level reinforce local inequalities. PED-CO does not, therefore, clearly endorse the fight against regional inequalities.

\section{FINAL CONSIDERATIONS}

A general examination of PED-CO makes it possible to identify, from a theoretical perspective, its ties with previous matrices of regional development as well as qualitative progress regarding its selected diagnostics and methodology, since the indicators involved offer more detailed 
information on the regional mosaic. Moreover, the document clearly provides a forecast of flows which, in theory, would capitalize several regions at the same time. However, since flows are based on the economic development matrix, they do not coincide with solutions to regional inequalities - such as those of Goiás' north-eastern portion already acknowledged by the literature (ARRAIS et al., 2010). Moreover, they do not solve infrastructural problems like lateral territorial integration (east-west direction) because the system of circulating and transporting goods and services remains focused on foreign markets - a topic widely covered by the literature. Given all this, one cannot conceive actual impacts in endo-regional integration.

Factors that inhibit growth - such as restrictions on infrastructure and cultivated areas - through legal and environmental mechanisms lead to stagnated production, which interferes directly on the regional dynamics. Furthermore, land conflict, a heritage of Brazil's territorial appropriation (MORAES, 2000), is a contemporary demand that poses a major challenge to the Centre-West's development. Land title instability combined with the profiles of large estates are two of the reasons behind the poor indicators that sometimes result from methodologies, as is the case with the methodology endorsed by PED-CO. Deforestation operates in these exact terms, yet another element making up 'new' (or old?) regional problems, not a solution to previous ones.

In summary, it is not enough to optimize the methodology brought forth by regional plans; it is also necessary to acknowledge the localist tradition that has been assigned to the New PNDR and to PED-CO through the notion of endogenous regional development, which in fact serves as an additional element in the obstruction of regional disparities. Moreover, PED-CO does not have a direct relation with structuring elements of the state policies that gave rise to and reinforced regional inequality. It is deficient in that it lacks a diagnostics that records the degree of mechanization in large estates or even the relation between production location and processing of grains and by-products, which in fact consolidates the regional development pattern from a technological point of view.

\section{ACKNOWLEDGEMENTS}

This article is part of the project entitled 'Novas determinações produtivas, regionais e urbanas na área do cerrado brasileiro: uma avaliação sobre os efeitos das obras de infraestrutura rodoferroviária no cerrado brasileiro' [New productive, regional, and urban determinations in the Brazilian savannah: assessing the effects of road and rail infrastructural works in the Brazilian savannah], financed by the Coordenação de Aperfeiçoamento de Pessoal de Nível Superior (Capes). The project's general aim consists in assessing the impacts of great works of road and rail infrastructure in the Brazilian Centre-West from the standpoint of urbanization, towards proposing a typology for understanding the urban network.

\section{BIBLIOGRAPHIC REFERENCES}

ANDRADE, Manuel Correia de. O planejamento regional e o problema agrário no Brasil. São Paulo: Hucitec, 1976. 180 p.

ARAÚJO, Tânia Bacelar de. Ensaios sobre o desenvolvimento brasileiro - heranças e urgências. Rio de Janeiro: REVAN, FASE, 2000.

ARRAIS, Tadeu A. Apontamentos metodológicos sobre desenvolvimento regional. Biblio 3W , Barcelona, v. XIV, n. 849, 2009. Disponível em: <http://www.ub.edu/geocrit/b3w-849.htm>. Acesso em: 28 out. 2016.

ARRAIS, Tadeu A. et al. Impactos territoriais dos programas estaduais de intervenção regional no Centro-Oeste: NE e N Goiano e entorno do Distrito Federal (1998-2006). Mercator, Fortaleza, v. 9, n. 18, p. 39-52, jan./abr. 2010. 
ASSIS, Luciene. Polinizadores em risco de extinção são ameaça à vida do ser humano. [2015?]. Disponível em: http://www.mma.gov.br/informma/item/9976-polinizadores-em risco-de-extincao-e-ameaca-a-vida-do-ser-humano>. Acesso em: 15 dez. 2016.

BARAT, Josef. O Investimento em Transporte como Fator de Desenvolvimento Regional. Revista Brasileira de Economia, Rio de Janeiro, v. 23, n. 3, p. 25-52, jul. 1969.

BENKO, Georges, LIPIETZ, Alain. As regiões ganhadoras - distritos e redes: os novos paradigmas da Geografia econômica. Portugal: Ed. Celta, 1994.

BRASIL. PAC. Em nove anos, investimentos executados pelo PAC somam R\$ 1,9 trilhão. Disponível em: < http://www.pac.gov.br/noticia/68777baf $>$. Acesso: 11/11/16.

BRASIL. Decreto n $\mathbf{7 5}^{\mathbf{7 5 . 3 2 0}}$, de 29 de Janeiro de 1975. Dispõe sobre a criação do Programa de Desenvolvimento dos Cerrados (POLOCENTRO). Disponível em: <http://www2.camara.leg.br/legin/fed/decret/1970-1979/decreto-75320-29-janeiro-1975-423871-publicacaooriginal-1-pe.html>. Acesso: 14/06/2016.

BRASIL. Decreto-Lei no 1.192, de 8 de Novembro de 1971. Cria o Programa de Desenvolvimento do Centro-Oeste (PRODOESTE), e dá outras providências. Disponível em: <http://www.planalto.gov.br/ccivil_03/ decreto-lei/1965-1988/Del1192.htm>. Acesso em: 10/07/2016.

BRASIL. Lei Complementar No 129, de 8 de janeiro de 2009. Institui, na forma do art. 43 da Constituição Federal, a Superintendência do Desenvolvimento do Centro-Oeste - SUDECO, e dá outras providências. Disponível em: < http://www.planalto.gov.br/ccivil_03/leis/LCP/Lcp129.htm>. Acesso: 09/07/2016.

BRASIL. Lei $\mathbf{N}^{0} \mathbf{5 . 3 6 5}$, de $1^{\circ}$ de dezembro de 1967. Cria a Superintendência do Desenvolvimento da Região Centro-Oeste (SUDECO), e dá outras providências. Disponível em: < http://www.planalto.gov.br/ccivil_03/ leis/1950-1969/L5365.htm>. Acesso: 09/07/2016.

BRASIL. Lei $\mathbf{n}^{0}$ 5.727, de 04 de Novembro de 1971. Dispõe sobre o Primeiro Plano Nacional de Desenvolvimento (PND), para o período de 1972 a 1974. Disponível em: <http://www.planalto.gov.br/ccivil_03/ leis/1970-1979/L5727.htm>. Acesso: 11/07/2016.

BRASIL. Lei $\mathbf{n}^{0}$ 6.151, de 04 de Dezembro de 1974. Dispõe sobre o Segundo Plano Nacional de Desenvolvimento (PND), para o período de 1975 a 1979. Disponível em: <http://www.planalto.gov.br/ccivil_03/ leis/1970-1979/L6151.htm>. Acesso: 11/07/2016.

BRASIL. Minist. da Integração Nacional. Superintendência do Desenvolvimento do Centro-Oeste. Histórico. 9 set. 2016. Disponível: <http://www.sudeco.gov.br/historico\#.V40qc_krK00>. Acesso em: 11 nov. 2016.

BRASIL. Plano Estratégico de Desenvolvimento do Centro Oeste (2007-2020). Brasília: Minist. da Integ. Nacional/MULTIVISÃO, 2007. 223 p. Disponível em: < www.sudeco.gov.br/pdco>. Acesso: 17/06/2016.

CASTRO, Gabriel. Atalhos de logística. Revista Veja, 14 jun. 2014. Disponível em: <http://veja.abril.com. br/brasil/atalhos-de-logistica/>. Acesso: 28/10/16.

CAVALCANTI, Marcelo Antunes; BARREIRA, Celene C. M. A. Ações da SUDECO no desenvolvimento do Centro-Oeste no estado de Goiás. Boletim Goiano de Geografia, v. 31, n. 2, p. 169-181, jan. 2012.

CHAVES, Manoel Rodrigues. Políticas de desenvolvimento regional: discriminação, (inter)nacionalização e (in)sustentabilidade do bioma Cerrado. In: GOMES, Horieste (coord.). Universo do Cerrado. Vol. 2. Goiânia: Ed, da UCG, 2008. p. 309-351.

CORREA, Vivian Helena Capacle; RAMOS, Pedro. A Precariedade do Transporte Rodoviário Brasileiro para o Escoamento da Produção de Soja do Centro-Oeste: situação e perspectivas. RESR, Piracicaba, SP, vol. 48, n ${ }^{\circ}$ 02, p. 447-472, abr/jun 2010.

CNT. Confederação Nacional do Transporte. Pesquisa CNT de rodovias 2015: relatório gerencial. Brasília: CNT: SEST: SENAT, 2015. 420 p.

CNT. Confederação Nac. do Transporte. Pesquisa rodoviária 2007. Brasília: CNT, 2007. 160 p.

DULONG, Renaud. A crise da relação Estado/sociedade local vista através da política regional. In.: POULANTZAS, Nicos. (Org.). O Estado em crise. Rio de Janeiro, Graal, 1977.

ELIAS, Denise. Relações campo-cidade, reestruturação urbana e regional no Brasil. In: COLOQUIO INTERNACIONAL DE GEOCRÍTICA, 12., 2012, Bogotá. Anais... Bogotá, 2012. Disponível em: <http:// www.ub.edu/geocrit/coloquio2012/actas/07-D-Elias.pdf>. Acesso em: 28 out. 2016. 
ESCOBAR, Arturo. Planejamento. In: SACHS, Wolfgang (Ed.). Dicionário do desenvolvimento: guia para o conhecimento como poder. Tradução de Vera Lucia M. Joscelyne, Susana de Gyalokay e Jaime A. Clasen. Petrópolis: Vozes, 2000. p. 211-228.

ESTEVA, Gustavo. Desenvolvimento. In: SACHS, Wolfgang (Ed.). Dicionário do desenvolvimento: guia para o conhecimento como poder. Tradução de Vera Lucia M. Joscelyne, Susana de Gyalokay e Jaime A. Clasen. Petrópolis: Vozes, 2000. p. 59-83.

GALVÃO, Antônio Carlos Filgueira. Política de Desenvolvimento regional e inovação: lições da experiência europeia. São Paulo: Garamond, 2004.

GOIÁS. Conjuntura Econômica Goiana. Goiânia: IMB, n. 39, dez. 2016. Disponível em: <http://www. imb.go.gov.br/viewcad.asp?id_cad=4039>. Acesso em: 15 dez. 2016.

GOIÁS. Decreto n ${ }^{\mathbf{0}} \mathbf{8 . 5 4 8}$, de 29 de janeiro de 2016. Altera o Decreto ${ }^{\circ}$ 4.852, de 29 de dezembro de 1997, Regulamento do Código Tributário do Estado de Goiás. Disponível em: $<$ http://www.gabinetecivil.go.gov. br/pagina_decretos.php?id=13975>. Acesso em 15 de Setembro de 2016.

GOODLAND, Robert; FERRI, Mário Guimarães. Ecologia do Cerrado. São Paulo: Ed. Itatiaia, 1979. 193 p. IBGE. Instituto Brasileiro de Geografia e Estatística. Censo 2010. Disponível em: $<$ http://censo2010.ibge. gov.br>. Acesso em: 15 set. 2016.

IBGE. Sistema IBGE de Recuperação Automática (SIDRA). Censo Agropecuário (1970, 1980 e 1995$).$ Disponível em: <https://sidra.ibge.gov.br/Tabela/264>. Acesso: 14/07/2016.

IBGE. Inst. Brasileiro de Geog. e Estatística. População nos Censos Demográficos por situação do domicílio (1960-2010). Disponível em: <http://www.censo2010.ibge.gov.br/sinopse/index.php?dados=8>. Acesso em: 15 set. 2016.

IBGE. Instituto Brasileiro de Geografia e Estatística. Produção Agrícola Municipal. Disponível em: <https://sidra.ibge.gov.br/Tabela/1612>. Acesso em: 10/11/2016.

IBGE. Inst. Brasileiro de Geog. e Estatística. Produto Interno Bruto per capita (2013). Disponível em: < http://www2.sidra.ibge.gov.br/bda/tabela/listabl.asp? $\mathrm{z}=\mathrm{t} \& \mathrm{o}=1 \& \mathrm{i}=\mathrm{P} \& \mathrm{e}=1 \& \mathrm{c}=1194>$. Acesso em: 14 nov. 2016.

INPE. Instituto Nacional de Pesquisas Espaciais. Projeto PRODES: Monitoramento da Floresta Amazônica Brasileira por Satélite. Disponível em: <http://www.obt.inpe.br/prodes/index.php>. Acesso em: 10/11/2016.

MDIC. Ministério do Desenv., Indústria e Comércio Exterior. Estatísticas de Comércio Exterior. Disponível em: $<$ http://www.mdic.gov.br/comercio-exterior/estatisticas-de-comercio-exterior $>$. Acesso em: 10/10/2016.

MDS. Ministério do Desenvolvimento Social. Cadastro Único: 2016. Disponível em: $<$ https://mds.gov.br/ assuntos/cadastro-unico>. Acesso em: 15 set. 2016.

LENCIONE, Sandra. Perspectivas Contemporaneas da Geografia Regional. In: Região e Geografia. LENCIONE, Sandra. São Paulo: Edusp, 2003. p.175-195.

MORAES, Antônio C. Robert. Bases da formação territorial do Brasil. São Paulo: Editora Hucitec, 2000. PERROUX, François. O conceito de pólo de desenvolvimento. In: FAISSOL, Speridião. (Org.). Urbanização e regionalização: relações com o desenvolvimento econômico. Rio de Janeiro: IBGE, 1975. p. 97-110.

RODRIGUES, Paulo Roberto A. Introdução aos sistemas de transporte no Brasil e à logística internacional. 4 ed. São Paulo: Aduaneiras, 2011. 246 p.

SACHS, Wolfgang. Introdução. In: (Ed.). Dicionário do desenvolvimento. Tradução de Vera Lucia M. Joscelyne, Susana de Gyalokay e Jaime A. Clasen. Petrópolis: Vozes, 2000. p. 11-17.

SANTOS, Milton; SILVEIRA, María Laura. O Brasil: território e sociedade no início do século XXI. Rio de Janeiro: Record, 2012. 473 p.

SOUZA, Marcelo L. A prisão e a ágora: reflexões em torno da democratização do planejamento e da gestão das cidades. Rio de Janeiro: Bertrand Brasil, 2006. 